\title{
What do Infertile Women Think about Oocyte Reception, Oocyte Donation, and Child Adoption?
}

\section{0 que as mulheres inférteis pensam em relação a ovo recepção, doação de oócitos e adoção de crianças?}

\author{
Juliana Straehl ${ }^{1}$ Lúcia Alves da Silva Lara ${ }^{1}$ Marcos Felipe Silva de Sá ${ }^{1}$ Rosana Maria Reis ${ }^{1}$ \\ Ana Carolina Japur de Sá Rosa-e-Silva ${ }^{1}$ \\ ${ }^{1}$ Human Reproduction sector, Department of Gynecology and \\ Obstetrics, Faculdade de Medicina de Ribeirão Preto, Universidade \\ de São Paulo, Ribeirão Preto, SP, Brazil

\begin{abstract}
Address for correspondence Lucia Alves da Silva Lara, Faculdade de Medicina de Ribeirão Preto, Universidade de São Paulo, Av. Bandeirantes, 3900, 14049-900 Ribeirão Preto, SP, Brazil (e-mail: luciaalvess@yahoo.com.br).
\end{abstract}

Rev Bras Ginecol Obstet 2017;39:282-287

\begin{abstract}
Keywords

- marital infertility

- oocyte donation

- adoption

- reproduction
\end{abstract}

\section{Resumo}

Purpose The views of infertile couples regarding oocyte donation by third parties and adoption are unknown, as these may be interpreted as a final closure of the available options for conception. This study aimed to determine the acceptance of oocyte donation, oocyte reception, and child adoption of infertile women who submitted to assisted reproductive technology (ART) treatment

Methods Sixty-nine women who were under treatment for infertility and submitted to ART procedures were included in this cross-sectional study. They were evaluated using semi-structured questionnaires administered during ovulation induction in a treatment cycle. Marital status, religion, years of schooling, occupation, type of infertility, age, duration of infertility, number of previous ART cycles, mean oocyte number per cycle, and mean number of embryos per cycle had no influence on a woman's acceptance of oocyte donation or oocyte reception.

Results More than $90 \%$ of the patients thought that the subject of "adoption" should be brought up during their ART treatments, although they preferred to discuss this topic with psychologists, not doctors. Women with occupations were more willing to consider adoption.

Conclusion The opinions of these patients on these issues seem to be based on personal concepts and ethical, religious, and moral values. Women preferred to discuss adoption with psychologists rather than doctors.

Objetivo Não se sabe ao certo o que os casais inférteis acham sobre doação de óvulos por terceiros e adoção, condições estas que podem ser interpretadas como um encerramento definitivo das opções disponíveis para concepção. Este estudo teve como objetivo determinar a aceitação da doação de oócitos, ovo recepção e adoção de crianças por mulheres inférteis submetidas a tratamento de reprodução assistida (RA).

Métodos Sessenta e nove mulheres em tratamento para infertilidade e submetidas a procedimentos de RA foram incluídas neste estudo transversal. Elas foram avaliadas por

received

August 20, 2016

accepted

March 13, 2017

published online

June 13, 2017
DOI https://doi.org/

$10.1055 / \mathrm{s}-0037-1603742$.

ISSN 0100-7203.
Copyright $\odot 2017$ by Thieme Revinter

Publicações Ltda, Rio de Janeiro, Brazil

License terms

c) $(1) \$$ 


\author{
Palavras-chave \\ - infertilidade conjugal \\ - doação de oocitos \\ - adoção \\ - reprodução
}

meio de questionários semiestruturados administrados durante a indução da ovulação em um ciclo de tratamento.

Resultados O estado civil, religião, escolaridade, ocupação, tipo de infertilidade, idade, duração da infertilidade, número de ciclos de RA anteriores, o número médio de oócitos por ciclo e de embriões por ciclo médio não tiveram influência sobre a aceitação da doação ou da recepção de oócitos. Mais de $90 \%$ das mulheres acha que o tema "adoção" deve ser discutido durante o tratamento de RA, porém preferem discutir este tema com psicólogos, e não com médicos. As mulheres com ocupações foram mais predispostas a considerar a adoção.

Conclusão As opiniões destas pacientes sobre estas questões parecem ser baseadas em conceitos pessoais e valores éticos, religiosos e morais. As mulheres preferiam discutir a adopção com psicólogos, em vez de médicos.

\section{Introduction}

The worldwide incidence of couple infertility, which ranges from $3.5 \%$ to $16.7 \%$ in developed countries and from 6.9 to $9.3 \%$ in less-developed countries, ${ }^{1}$ has been increasing in recent decades. Many men and women currently opt to postpone pregnancy because of professional or other responsibilities, ${ }^{2}$ but fertility is currently a concern of many women who seek counseling regarding the postponement of pregnancy. ${ }^{3}$ Advanced age has a negative impact on female fertility, ${ }^{4}$ although other factors may also cause infertility in women (for example, malformations of the genital tract, infectious processes, endometriosis, myometrial and endometrial injuries, ovarian, pituitary or thyroid factors) and in men.

Many factors may cause infertility in men, and idiopathic oligoasthenoteratozoospermia (IO) is present in up to $30 \%$ of infertile men. Such condition may be linked to age, noninflammatory functional alterations in post-testicular organs, infective agents, alterations in gamete genome, mitochondrial alterations, environmental pollutants, and hormonal alterations. ${ }^{5}$

Infertile couples increasingly seek assisted reproduction (AR), although these services are not within reach of all couples, especially those in developing countries. Thus, fewer than $25 \%$ of infertile persons receive AR treatment worldwide. ${ }^{1}$ When AR is not possible, or if AR fails, there are other resources such as a surrogate uterus, oocyte or embryo donation, and child adoption. ${ }^{6}$

Oocyte donation has been used since the 1980 s, $^{7-9}$ and the results are comparable to those of patients who use their own oocytes in terms of the rate of embryo implantation, birth weight, gestational age at birth, perinatal mortality, and lactation. ${ }^{10}$ Oocyte donation is indicated when there is premature ovarian failure, genetic anomalies with possible hereditary transmission, repeated failure of in vitro fertilization, poor response to ovarian stimulation, repeated spontaneous abortions, ${ }^{11}$ and in other conditions. In some countries, restrictions limit the access to oocyte donation. ${ }^{12}$ In countries where oocyte donation is widespread, there are ethical concerns about the possible abuse of donation by poor women. In addition, potential donors may falsify their health records to be accepted into these programs, and this may increase the risk of transmission of infectious diseases and hereditary defects. However, some research suggests that the characteristics of oocyte donors does not depend on remuneration. ${ }^{13}$

Adoption is another alternative that couples for whom AR treatment has failed should consider. However, adoption should not be seen as a treatment of infertility, but rather as an option for infertile couples who wish to be parents. ${ }^{14}$ In Brazil, $\sim 35 \%$ of all adoptions are sought by infertile couples. ${ }^{15}$ In the United States, men tend to seek adoptions after they have already used infertility services and women tend to seek adoptions at the end of their reproductive periods and after unsuccessful AR treatment. ${ }^{16}$ However, adoption may not satisfy a couple if they wish the physical experience of pregnancy, birth, and breastfeeding. Such couples may instead opt for gamete donation (GD). Indeed, many couples must decide between GD and adoption. For many couples, the reasons for choosing GD rather than adoption range from the practical to the emotional, and include the perceived negative aspects of adoption and perceived advantages of GD. ${ }^{17}$ There is limited literature about the impact of different treatment approaches for couples who experience repeated AR failures. The views of these couples regarding oocyte donation by third parties and adoption are unknown, and these may be interpreted as a final closure of the available options.

In view of the limited research on this topic, the objective of the present study was to determine the acceptance of oocyte donation, oocyte reception, and child adoption of infertile women who submitted to AR treatment.

\section{Methods}

This cross-sectional study consecutively enrolled women who were under treatment for infertility and submitted to AR procedures in the Laboratory of the Sector of Human Reproduction, Department of Gynecology and Obstetrics, at the Faculdade de Medicina de Ribeirão Preto, Universidade de São Paulo (FMRP-USP), over a period of 6 months (2013 to 2014). The women were recruited by a female gynecologist during the process of cycle monitoring for AR. 
All women responded to a semi-structured questionnaire that had 14 questions about sociodemographic and clinical data. The questionnaire had open questions, and questions with optional replies or with the possibility of more than one reply regarding oocyte donation, oocyte reception, and adoption. The assayed sociodemographic characteristics included marital status (married, cohabiting, or single), religion (Catholic, Evangelical, Spiritualist, other), years of study in school $(8,12$, or 17$)$, and working status (remunerated worker or housewife). The type of infertility was classified as primary or secondary.

The questionnaire used to assess women's feelings and decisions on oocyte donation, oocyte reception, and child adoption contained the questions listed in -Table $\mathbf{1}$.

The questionnaires were administered before the beginning of the AR cycle or during ovarian induction. This was predominantly a qualitative investigation. This study was approved by the Research Ethics Committee of the University Hospital, FMRP-USP, and all patients gave written informed consent to participate.

\section{Statistical Analysis}

The patients were divided into groups according to their responses (yes or no) to the following variables: oocyte donation, oocyte reception, and child adoption. The influences of sociodemographic and clinical characteristics on the responses to these questions were determined.
The Fisher exact test was used to determine the association between two qualitative variables using the PROC FREQ feature of SAS® 9.0 (Cary, NC, USA). The nonparametric Mann-Whitney test for independent samples (Conover, 1981) was used to compare two groups in terms of quantitative variables using the PROC NPAR1WAY feature of SAS ${ }^{8} 9.0$ (Cary, NC, USA). The level of significance was set at $p<0.05$ in all analyses.

\section{Results}

We invited 112 women to participate in the study. Forty-three women refused to participate without stating the reasons for their decisions. Thus, 69 women (mean age: 34.5, SD: 4.2 years, range: 23-44 years) were included in the study (-Table 2 ).

Among the 69 participants, 4 (5.79\%) had never heard about oocyte donation and 32 (46.4\%) were not willing to donate their oocytes. Among these 32 patients, 21 (65.6\%) stated they did not want other women to carry their biological offspring, 8 (28.12\%) stated that they did not know the details of the technique and its implications, and 3 (6.25\%) did not approve of the technique for religious reasons.

Marital status $(p=0.99)$, religion $(p=0.49)$, years of schooling ( $p=0.87)$, occupation ( $p=0.50)$, and type of infertility (primary versus secondary) $(p=0.79)$ had no influence on the decision to donate oocytes.

Table 1 Semi-structured questionnaire used to assess women's acceptance of oocyte donation, oocyte reception, and child adoption

\begin{tabular}{|c|c|}
\hline Questions & Responses \\
\hline Have you heard about oocyte donation previously? & Yes/no \\
\hline Would you donate your oocytes? & Yes/no \\
\hline If the response was "no" to the previous question, then why? & $\begin{array}{l}\text { Religious factors/do not want children that are not mine to } \\
\text { carry my genetic load/I am not familiar with the technique } \\
\text { and its implications/others }\end{array}$ \\
\hline $\begin{array}{l}\text { If you are unsuccessful in your attempts at ICSI, would you } \\
\text { accept the oocytes of a donor? }\end{array}$ & Yes/no \\
\hline \multicolumn{2}{|l|}{ Why? } \\
\hline $\begin{array}{l}\text { If you became pregnant, would you donate your oocytes to } \\
\text { another patient? }\end{array}$ & Yes/no \\
\hline Have you ever thought about adoption? & Yes/no \\
\hline Have you talked to your partner about adoption? & Yes/no \\
\hline In your opinion, when should adoption be considered? & $\begin{array}{l}\text { Never/after } 1 \text { attempt to treat infertility/after } 2 \text { attempts to treat } \\
\text { infertility/after } 3 \text { attempts to treat infertility/after } 4 \text { or more } \\
\text { attempts to treat infertility/only after entering menopause/ } \\
\text { when there are no more financial resources for treatment of } \\
\text { infertility/when there are no more emotional resources for } \\
\text { treatment of infertility/others }\end{array}$ \\
\hline $\begin{array}{l}\text { Do you think the health team that assists you during your AR } \\
\text { treatment should discuss the topic of adoption? }\end{array}$ & Yes, always/no, always/only if the couple asks \\
\hline \multicolumn{2}{|c|}{ If you answered yes to the previous question, respond to the next two questions } \\
\hline When is the best time to discuss the possibility of adoption? & $\begin{array}{l}\text { During the first visit/after a first treatment failure/after } \\
\text { repeated treatment failures (state how many) }\end{array}$ \\
\hline Who do you think should approach this topic? & Doctor/nurse/psychologist/other \\
\hline
\end{tabular}

Abbreviations: AR, assisted reproduction; ICSI, intracytoplasmic sperm injection. 
Table 2 Characteristics of women undergoing assisted reproduction techniques who would donate oocytes, receive oocytes, and thought about adoption $(N=69)$

\begin{tabular}{|c|c|c|c|c|c|c|c|c|c|}
\hline \multirow[t]{3}{*}{ Variable } & \multicolumn{3}{|c|}{ Would donate oocytes? } & \multicolumn{3}{|c|}{ Would receive oocytes? } & \multicolumn{3}{|c|}{ Thought about adoption? } \\
\hline & $\begin{array}{l}\text { Yes } \\
(N=32)\end{array}$ & $\begin{array}{l}\text { No } \\
(N=37)\end{array}$ & $p$ & $\begin{array}{l}\text { Yes } \\
(N=29)\end{array}$ & $\begin{array}{l}\text { No } \\
(N=40)\end{array}$ & $p$ & $\begin{array}{l}\text { Yes } \\
(N=59)\end{array}$ & $\begin{array}{l}\text { No } \\
(N=10)\end{array}$ & $p$ \\
\hline & \multicolumn{9}{|l|}{ Mean \pm SD } \\
\hline Age (years) & $33.95 \pm 4.42$ & $34.81 \pm 3.99$ & 0.51 & $33.90 \pm 4.71$ & $34.68 \pm .79$ & 0.61 & $34.46 \pm 4.20$ & $33.70 \pm 4.22$ & 0.46 \\
\hline Years of infertility & $5.88 \pm 4.35$ & $4.91 \pm 2.73$ & 0.77 & $6.43 \pm 4.68$ & $4.69 \pm 2.61$ & 0.37 & $5.67 \pm 3.88$ & $4.00 \pm 1.91$ & 0.37 \\
\hline $\begin{array}{l}\mathrm{N}^{\circ} \text { of previous } \\
\text { cycles }\end{array}$ & $0(0-1)$ & $1(0-1)$ & 0.53 & $1(0-1)$ & $0(0-1)$ & 0.75 & $1(0-1)$ & $0(0-1)$ & 0.58 \\
\hline $\begin{array}{l}\text { Oocytes in } \\
\text { previous cycles }\end{array}$ & $4.51 \pm 4.90$ & $7.86 \pm 5.27$ & 0.08 & $4.09 \pm 3.24$ & $8.01 \pm 6.00$ & 0.10 & $6.13 \pm .99$ & $7.42 \pm 8.02$ & 0.84 \\
\hline $\begin{array}{l}\text { Embryos in } \\
\text { previous cycles }\end{array}$ & $2.21 \pm 2.60$ & $3.56 \pm 3.03$ & 0.24 & $2.16 \pm 1.73$ & $3.53 \pm 3.14$ & 0.35 & $2.82 \pm 2.42$ & $3.71 \pm 4.50$ & 0.99 \\
\hline
\end{tabular}

Abbreviations: $\mathrm{N}$, number; $\mathrm{p}$, p-value; SD, standard deviation

A comparison between the women who said they would and the ones who said they would not donate oocytes indicated no significant differences in age, time of infertility, number of previous AR cycles (IVF and/or ICSI), mean number of oocytes retrieved per cycle, and mean number of embryos formed per cycle (-Table 2 ).

Forty of the 69 women (58.0\%) stated that they would not receive oocytes from a donor and 10 (14.49\%) said they did not think about adoption, even after unsuccessful treatment with their own oocytes. Comparisons between the women who said they would and the ones who said they would not receive oocytes and between the women who said they would or would not consider adoption also indicated no significant differences in age, time of infertility, number of previous cycles, number of oocytes obtained in previous cycles, or number of embryos formed (-Table 2 ).

Marital status, religion, amount of schooling, occupation, and type of infertility (primary or secondary) had no influence on the consideration of adoption in either subgroup, although women who worked outside the home thought about adoption more than those who were housewives $(p=0.03)$ (-Fig. 1).

Fifty-nine of the 69 women (85.51\%) had already thought about adoption and discussed the topic with their partners, but only 5 (8.47\%) were willing to adopt, and 54 (91.5\%) stated that they would adopt only in the case of AR failure.

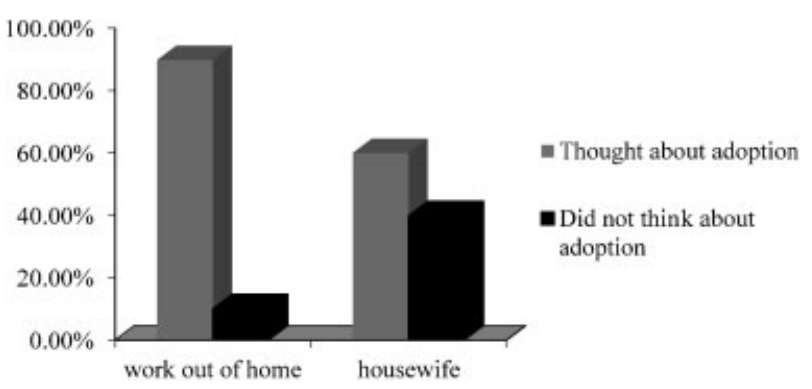

Fig. 1 Percentage of women receiving assisted reproduction techniques (ART) who worked outside the home or were housewives and considered adoption of a child.
Five (7.24\%) women stated they would never consider adoption, 37 (53.6\%) stated that adoption should always be considered, and 27 (39.1\%) that it should be considered only when questioned by a professional. Among patients who said that adoption should be considered, 15 (23.4\%) responded that a doctor should approach them on this topic, $10(15.6 \%)$ that doctors and psychologists should jointly approach them on this topic, and 39 (60.93\%) that only a psychologist should approach them on this topic.

\section{Discussion}

The objective of the present study was to evaluate the characteristics of women undergoing AR treatment regarding their acceptance of oocyte donation, oocyte reception, and child adoption and to determine the preferences of these women regarding which health professional should discuss the topic of adoption. The results demonstrated that almost half (46.4\%) of the study population would not donate oocytes, mostly (65.6\%) because they did not want another woman to carry their genetic offspring. None of the assessed sociodemographic or clinical characteristics of these patients was significantly associated with a willingness to donate oocytes. Most women's opinions on these matters were exclusively based on personal concepts of an ethical, religious, or moral nature. The women's most frequently mentioned reason for an unwillingness to donate oocytes is that they did not want another woman to carry their genetic offspring.

In the US, government regulations regarding oocyte donation focus on the dissemination of infectious diseases and rates of successful reproduction, and do not consider the psychological aspects of women undergoing the procedure. ${ }^{18}$ However, previous studies have examined the ethical, economic, and psychological aspects of oocyte donation and reception. ${ }^{19} \mathrm{~A}$ study of oocyte sharing in a sample of 48 donors and 38 recipients indicated that donors and recipients expressed divergent feelings. Some women maintained positive reciprocal feelings and were willing to keep a future relationship with their counterparts, but others did not intend to maintain this relationship and did not wish to learn about the results of the 
conception. ${ }^{20}$ Another study of couples stated that oocyte recipients preferred not to know about the origin of the oocytes, so that the child would be raised according to the family standards of the recipient. ${ }^{21}$ Although most oocyte recipients do not think about the biological origins of their babies, oocyte donors frequently think about the babies born from their donated oocytes, whether these children are loved, if they have characteristics of the donors, and if they are happy. ${ }^{19}$ Some women also express negative feelings about their biological child belonging to another person. ${ }^{20}$ In our study, the second most frequent reason for not donating oocytes is a lack of knowledge about the technique and its implications. This suggests that educational measures that provide information about oocyte transfer and its implications during initial treatment would be useful to support the recruitment of potential oocyte donors.

An interesting finding of the present study is that women who received a larger number of oocytes or embryos in previous cycles did not favor the option of oocyte donation. On the contrary, women with a smaller number of oocytes in previous cycles were more likely to donate oocytes although this difference was not statistically significant. During our interviews on oocyte donation, some women stated that "they would donate because, like many other women, it was their dream to be a mother," or "they would donate to help women with the same wish as theirs to be mothers," or "they would donate to help a woman who is in the same situation as theirs."

When asked if they would receive donated oocytes, $53.0 \%$ of our women responded they would not because the child would not be their biological child, and that they would prefer to adopt. Karpel et $\mathrm{al}^{22}$ reported contrary results in 2007. In that study, women who wanted to receive oocytes sought to have the experience of pregnancy, delivery, and breastfeeding above anything else. The possibility of semen being from the biological father may contribute to this decision, because both partners would play a role in conception. A previous study demonstrated that parents of children from female or male gametes think less about these children not being their biological children than the parents of adopted children. ${ }^{23}$

Most of the characteristics that we examined in the couples undergoing AR treatment were unrelated to the contemplation of adoption as an alternative to conception. However, women who held paying jobs thought more about adoption than women who were housewives. Previous studies demonstrated that women with a remunerated job who are able to develop a maternal role of good quality had better psychological well-being, although they were more susceptible to the stress associated with overwork. ${ }^{24,25}$ Further research is needed to determine the reasons why housewives think less about adoption than working women. It may be that housewives create expectations about a family in which their ability to gestate and generate children is a key part of their primary role in their relationship.

In the present study, although patients who considered adoption as an option had already discussed it with their partners, only a small proportion of them (8.47\%) appeared ready for adoption according to the questionnaire. Jones ${ }^{16}$ reported that $84.5 \%$ of couples who opt for AR procedures think about adoption when they are informed that they are infertile, $29 \%$ initiate the adoption process, but only $18 \%$ really intend to adopt a child. Most couples do not wait for counseling with their doctors to become interested in adoption, but they need to hear that there are really no chances of successful AR treatment before they become interested in adoption. ${ }^{22}$ This suggests that most patients seek successful $\mathrm{AR}$, greatly wishing to obtain personal and/or social proof that they can generate a child. It is not simply the wish to be a mother, but the gestation of a baby that seems to play a fundamental role in this objective. In this respect, MacCal$\operatorname{lum}^{23}$ reported that the parents of children obtained by embryo donation (similar to oocyte donation) can more readily accept that their children are not biologically related than the parents of adopted children. ${ }^{23}$ Thus, embryo or GD can be considered to be an important alternative to adoption. In the present study, most women stated that they only considered adoption as a possibility in cases of repeated treatment failure or when the financial or emotional resources involved in AR treatment were exhausted.

When the women were asked about being approached by a professional regarding adoption, most stated that the subject should be approached at some time (92.8\%), but many (39.1\%) felt that the subject should only be discussed when brought up by the patient. Most patients who thought that the topic should be discussed (60.9\%), also thought that it should be raised by a psychologist. This may be because they believe psychologists are better equipped to approach the complex and conflicting topics regarding adoption or perhaps because discussion of this matter with a doctor may suggest to them that it is a "last option."

There are no well-established criteria in the literature about when a woman should consider the impossibility of gestation and stop AR treatment. This decision, which in principle should be made by the doctor, is somewhat subjective, and usually causes anguish and discomfort to the doctor. Although adoption is not a treatment for infertility, it is an option for couples who wish to have a child and may improve the quality of their lives. ${ }^{26}$

\section{Conclusion}

No previous studies have identified the clinical or demographic characteristics of women who would donate their oocytes, who would receive oocytes from another woman, or who would adopt a child. Instead, these decisions appear to be based on individual experiences and opinions. However, women who held jobs outside the home were significantly more likely to accept adoption than housewives.

Most of our patients thought that the topic of adoption should be mentioned during the AR treatment, although almost half of them believed that the patient herself-not the professional team - should begin discussion of this topic. About $60 \%$ of the patients stated that they preferred to discuss the topic of adoption with a psychologist without the participation of a doctor. 


\section{Acknowledgments}

We thank Océlia Vasconcelos and Maria Cristina Brentigani for the great contribution to this work

\section{References}

1 Boivin J, Bunting L, Collins JA, Nygren KG. International estimates of infertility prevalence and treatment-seeking: potential need and demand for infertility medical care. Hum Reprod 2007;22 (06):1506-1512

2 Daniluk JC, Koert E. Childless Canadian men's and women's childbearing intentions, attitudes towards and willingness to use assisted human reproduction. Hum Reprod 2012;27(08):2405-2412

3 Birch Petersen K, Hvidman HW, Sylvest R, et al. Family intentions and personal considerations on postponing childbearing in childless cohabiting and single women aged 35-43 seeking fertility assessment and counselling. Hum Reprod 2015;30(11):2563-2574

4 Berglund Scherwitzl E, Lindén Hirschberg A, Scherwitzl R. Identification and prediction of the fertile window using NaturalCycles. Eur J Contracept Reprod Health Care 2015;20(05):403-408

5 Cavallini G. Male idiopathic oligoasthenoteratozoospermia. Asian J Androl 2006;8(02):143-157

6 Ricci G, Delbon P, Conti A, Sirignano A. [Literature review and state of the art of the Italian law on medically assisted reproduction]. Clin Ter 2015;166(03):e234-e241 Italian

7 Asch R, Balmaceda J, Ord T, et al. Oocyte donation and gamete intrafallopian transfer as treatment for premature ovarian failure. Lancet 1987;1(8534):687

8 Cobo A, Garrido N, Pellicer A, Remohí J.Six years' experience in ovum donation using vitrified oocytes: report of cumulative outcomes, impact of storage time, and development of a predictive model for oocyte survival rate. Fertil Steril 2015;104(06):1426-34.e1, 8

9 Figueira RdeC, Setti AS, Braga DP, Iaconelli A Jr, Borges E Jr. The efficiency of a donor-recipient program using infertile donors' egg cryo-banking: a Brazilian reality. J Assist Reprod Genet 2014;31 (08):1053-1057

10 Zegers-Hochschild F, Masoli D, Schwarze JE, Iaconelli A, Borges E, Pacheco IM. Reproductive performance in oocyte donors and their recipients: comparative analysis from implantation to birth and lactation. Fertil Steril 2010;93(07):2210-2215

11 Letur H. [Current practices of oocyte donation in France and Europe]. J Gynecol Obstet Biol Reprod (Paris) 2007;36(08):727-737 French
12 Guilhem D. New reproductive technologies, ethics and legislation in Brazil: a delayed debate. Bioethics 2001;15(03):218-230

13 German EK, Mukherjee T, Osborne D, Copperman AB. Does increasing ovum donor compensation lead to differences in donor characteristics? Fertil Steril 2001;76(01):75-79

14 Horwath D, Check JH, Katsoff B, Amui J, Brasile D. Subsequent therapeutic options and outcome in couples who fail to fertilize despite in vitro fertilization (IVF) and intracytoplasmic sperm injection (ICSI). Clin Exp Obstet Gynecol 2007;34(02):109-110

15 Mariano FN, Rossetti-Ferreira MC. [What's the profile of the biological, adopting families and adopted child as revealed by the judicial processes?] Psicol Reflex Crit 2008;21(01):11-19 Portuguese

16 Jones J. Who adopts? Characteristics of women and men who have adopted children. NCHS Data Brief 2009;(12):1-8

17 Daniels KR. Adoption and donor insemination: factors influencing couples' choices. Child Welfare 1994;73(01):5-14

18 Alberta HB, Berry RM, Levine AD. Compliance with donor age recommendations in oocyte donor recruitment advertisements in the USA. Reprod Biomed Online 2013;26(04):400-405

19 Holwell E, Keehn J, Leu CS, Sauer MV, Klitzman R. Egg donation brokers: an analysis of agency versus in vitro fertilization clinic websites. J Reprod Med 2014;59(11-12):534-541

20 Gürtin ZB, Ahuja KK, Golombok S. Emotional and relational aspects of egg-sharing: egg-share donors' and recipients' feelings about each other, each others' treatment outcome and any resulting children. Hum Reprod 2012;27(06):1690-1701

21 Bertrand-Servais M, Letur-Könirsch H, Raoul-Duval A, Frydman R. [Recipients of oocytes donated anonymously. Psychological aspects]. J Gynecol Obstet Biol Reprod (Paris) 1992;21(07):743-749 French

22 Karpel L, Frydman N, Hesters L, Fanchin R, Frydman R, Flis-Trèves M. [Talking about adoption during IVF]. Gynecol Obstet Fertil 2007;35(03):232-239 French

23 MacCallum F. Embryo donation parents' attitudes towards donors: comparison with adoption. Hum Reprod 2009;24(03):517-523

24 Oster KA, Scannell ED. Change in role perception, role conflict, and psychological health of working mothers. Psychol Rep 1999; 84(01):221-230

25 Tang CS, Lee AM, Tang T, Cheung FM, Chan C. Role occupancy, role quality, and psychological distress in Chinese women. Women Health 2002;36(01):49-66

26 Johansson M, Adolfsson A, Berg M, et al. Quality of life for couples 4-5.5 years after unsuccessful IVF treatment. Acta Obstet Gynecol Scand 2009;88(03):291-300 